\title{
Effect of Yolk and White on Shear-Stable Emulsion Preparation from Fish
}

\author{
Teruo Nakayama ${ }^{*}$, Yumiko Tozaki ${ }^{*}$, Atsuko Wakabayashi* \\ and Atsushi Oor* \\ * Faculty of Bioresources, Mie University, \\ 1515, Kamihama-cho, Tsu, Mie 514
}

The effect of an added amount of egg yolk or egg white on the consistency of new emulsified product prepared from fish was investigated. The flow property of the emulsified product was expressed by the power law equation including the exponent, $n$. In the product with yolk-ratios of 0.1 and 0.2 , the structure breakdown was significant during the rotational measurement of flow property, since the difference in yield stress value was large between the increasing and decreasing shear rate determinations; the shear stress was large in the increasing shear rate depending on large $\mathrm{n}$ values and it was small in the decreasing shear rate depending on small $n$ values. The absolute values of yield stress obtained from the compressive measurement of the flow property were almost the same as those from the rotational measurement of the flow property. The hysteresis loop area surrounded by the increasing and decreasing shear rate curves was large for a yolk-ratio of 0.1 while it was small for a yolk-ratio between 0.3 and 0.6 . The product with a yolk ratio of 0.2 was in the transition state from a shear-unstable emulsion to a shear-stable one. Both storage modulus, $G^{\prime}$, and loss modulus, $G$ ", decreased with the increase of yolk-ratio. The $G^{\prime \prime}$ value was larger than the $G^{\prime}$ value for the product with any yolk-ratio. It was found from the above results that with yolk-ratio of 0.3 or more, the shear-stable emulsion was prepared.

In the white-added product, the yield stress obtained from the compressive measurement of the flow property increased with the increase in white-ratio from 0.2 to 0.5 and decreased with the ratio of 0.6 . This tendency coincided with that observed in the hysteresis loop area obtained from the rotational measurement of the flow property. For the white-ratios from 0.2 to 0.5 , the yield stress values obtained from the compressive measurement of the flow property were almost the same as those obtained from the increasing shear rate determination of the rotational flow property. However, for the ratio of 0.6 , the former yield stress value was one-half of the latter. Both the storage modulus, $G^{\prime}$ and loss modulus, $G^{\prime \prime}$, increased with the increase in white-ratio from 0.2 to 0.5 but decreased for the ratio of 0.6 . For the ratios of 0.2 and 0.3 , the $G^{\prime}$ value was almost equal to the $G^{\prime \prime}$ value while for the ratio of 0.4 or more, the former value was larger than the latter. The white-added product was brittle, as shown in these results.

In our previous study ${ }^{1)}$, a new emulsified product was produced from sardine meat preparation with very low lipid content. To produce this sardine meat preparation, the minced meat of fresh sardine was suspended in 4 volumes of cold $0.1 \% \mathrm{NaHCO}_{3}$ and $0.1 \% \mathrm{NaCl}$ solution. The dehydration of suspended minced meat was done by continuous centrifugation through a decanter. The continuous centrifu- gation used in our previous research was much more effective than the rotary screen and screw press dehydration of ordinary sardine surimi processing. In our continuous centrifugation, the lipid and blood which were the cause of the fishy odor, were effectively removed. As a result, the fishy odor was not detected at all in our sardine meat preparation with very low lipid content. This sardine meat preparation 
was emulsified by adding soybean oil, whole egg and vinegar. The fishy odor was also not detected in the emulsified product. The product was light- and cream-colored, and had a fine-grained and smooth texture.

The viscoelastic consistency of our product was almost equal to or larger than that of commercial mayonnaise and remained almost unchanged for 4 weeks of cold storage. It is considered from the consistency and stability evaluations that our product is promising as a dressing-type food. In the previous manufacturing of a new emulsified product ${ }^{1}$, whole egg was used as a emulsifier. Whole egg is composed of egg yolk and egg white. These components will play different roles when whole egg is used. Egg yolk is more concentrated than egg white, containing less water, more protein, and a considerable amount of $\mathrm{fat}^{2}$. In the present work, the effect of an added amount of egg yolk or egg white on the consistency of new emulsified product was investigated.

The viscosity evaluation of semi-solid food in one's mouth is based on the flow characteristics in the narrow channel formed by the tongue's surface and the hard palate ${ }^{3)}$. The spreadability evaluation of dressing-type food is based on the rate at which the samples spread $^{3)}$. A shear rate dependent profile of our product including yield stress and structure breakdown is very important in this sense. Its response to rotational, compressive, and vibrational flow is also important. Therefore, these properties were measured based on the consistency evaluation of our product, and the relationship between the emulsifier content and the consistency of the emulsified product was discussed.

\section{Materials and Methods}

Manufacturing of new emulsified product

Sardine meat preparation with very low lipid content was prepared in the pilot plant of Taiyo Fishery Co., Ltd. at Nagasaki prefecture as previously reported ${ }^{1)}$. The sardine meat preparation thus obtained was designated PMM as the abbreviation for Purified Minced
Meat and hereinafter referred to as PMM in this study. The composition of PMM was estimated as follows : $77.3 \%$ moisture, $14.9 \%$ protein, $1.7 \%$ lipid, $0.8 \%$ ash, $5.0 \%$ carbohydrate (additive). PMM was put into a plastic bag, tightly sealed, and stored frozen at $-40^{\circ} \mathrm{C}$. The new emulsified product was prepared from PMM as previously reported ${ }^{1)}$. The ratios of soybean oil and vinegar to PMM in the product were 1.1 and 0.14 , respectively. The ratio of emulsifier to PMM, ranged from 0.1 to 0.6 . As an emulsifier, either egg-yolk or egg-white was used.

Examination of.consistency of new emulsified product

Three experimental methods were used to investigate the consistency of the new emulsified products.

(1) Rotational measurement of flow property : The shear rate sweep measurement was carried out with a cone-and-plate rheometer (NRM-100, Nihon Rheology Kiki Co., Ltd.) using the cone (top platen) with $3^{\circ}$ angle and $3.68 \mathrm{~cm}$ radius. The plate (bottom platen) of the instrument was thermostated at $5 \pm 0.2^{\circ} \mathrm{C}$. The maximum shear rate was $200 \mathrm{~s}^{-1}$, and the sweep times taken for the increasing shear rate curve (hereinafter called upcurve) and the decreasing shear rate curve (downcurve) were both $100 \mathrm{~s}$.

(2) Compressive measurement of flow property : The yield stress was determined with a compression-type rheometer (RE-3305, Yamaden Co., Ltd.) using parallel plates $4 \mathrm{~cm}$ in diameter. Sample temperature was kept at $5^{\circ} \mathrm{C}$ using the temperature control unit designed for this experiment. The initial sample height was set at $0.6 \mathrm{~cm}$ and the excessive stress was set free. A constant force $W(\mathrm{~N})$ was then applied to the sample and the limiting sample height $H(\mathrm{~m})$ was obtained after $20 \mathrm{~min}$ to calculate the yield stress $C,\left(\mathrm{~Pa}\right.$ or $\left.\mathrm{N} \cdot \mathrm{m}^{-2}\right)$, as :

$$
C=\frac{3 W H}{2 \pi R^{3}}
$$

where $R(\mathrm{~m})$ is the radius of the parallel plates ${ }^{4)}$.

(3) Vibrational measurement of flow pro- 
perty: The dynamic viscoelasticity of the sample was examined with a rheometer (Rheolograph Type 653, Toyo Seiki Mfg. Co., Ltd.) and evaluated in terms of the storage modulus, $G^{\prime}$, and loss modulus, $G^{\prime \prime}$. The temperature of the sample was $5^{\circ} \mathrm{C}$. The strain amplitude was $10 \%$, and the frequency was 3 cycle/s.

\section{Microscopic observation}

The prepared slides of new emulsified product were observed under a microscope (OPTIPHOT, Nikon Co., Ltd.) with a $40 \mathrm{X}$ objective and a $10 \mathrm{X}$ ocular. Photographs were taken with an automatic photographing system (MICROFLEX AFX-IIA, Nikon Co., Ltd.).

\section{Results}

Consistency of emulsified product with various amounts of egg-yolk

The response to the rotational measurement of flow property is shown in Fig. 1 where the hysteresis behavior of the emulsified product with increasing and decreasing shear rate determination is displayed. An upcurve was obtained when shear rate was increased from $0 \mathrm{~s}^{-1}$ to $200 \mathrm{~s}^{-1}$ and a downcurve was obtained when shear rate was decreased from $200 \mathrm{~s}^{-1}$ to $0 \mathrm{~s}^{-1}$. The yield stresses were detected at the shear rate of $0 \mathrm{~s}^{-1}$ on the start and end of the shear application. The yield stress of the upcurve decreased with the increase of egg-yolk

\section{Emulsifier : Egg-yolk}
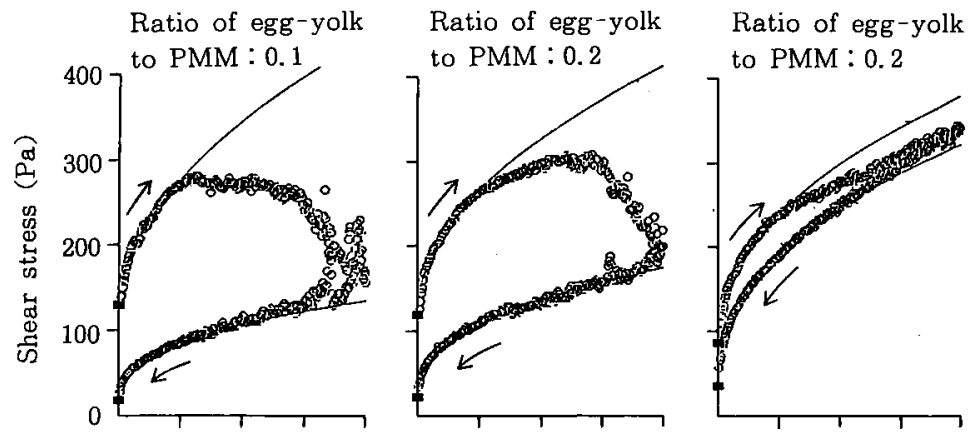

Ratio of egg-yolk to $P M M: 0.3$
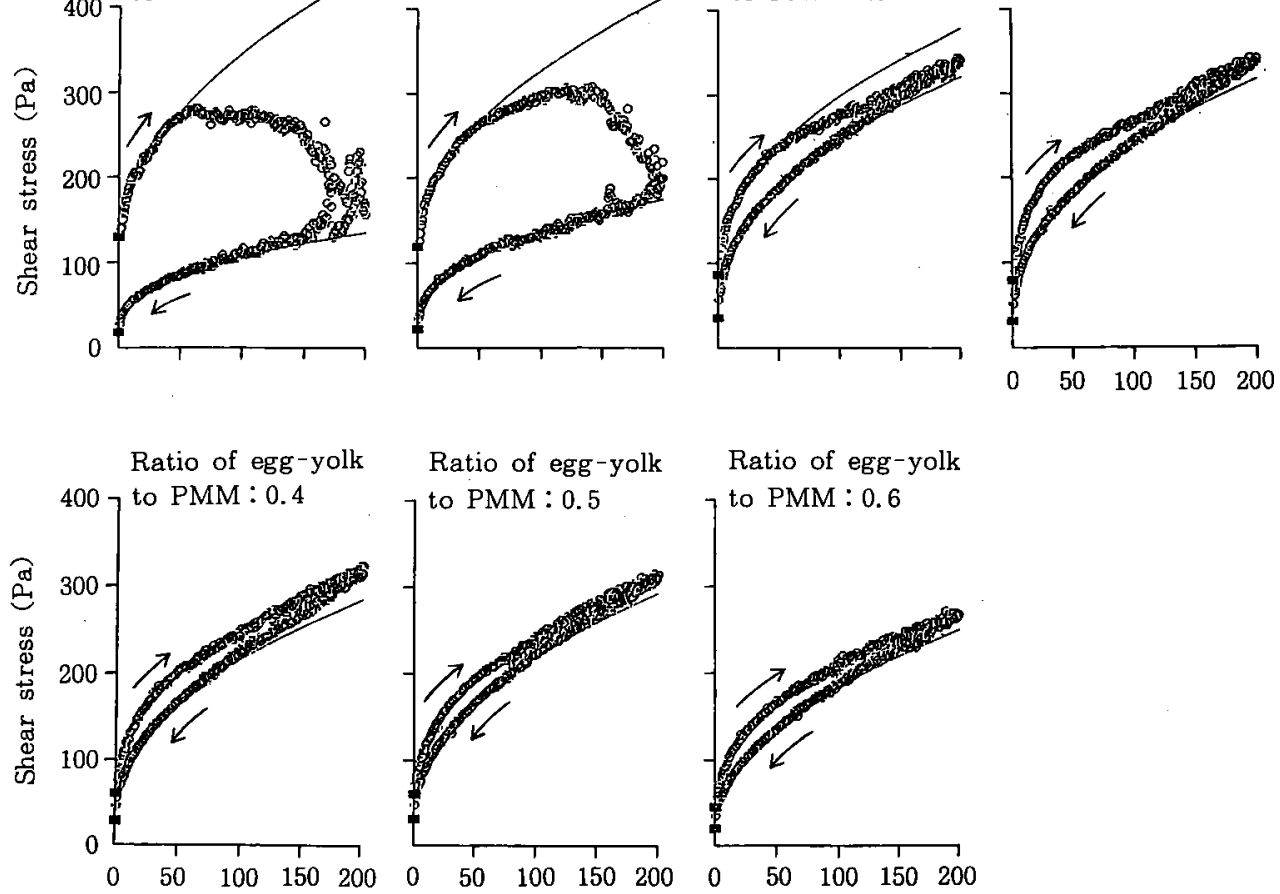

Ratio of egg-yolk

Ratio of egg-yolk
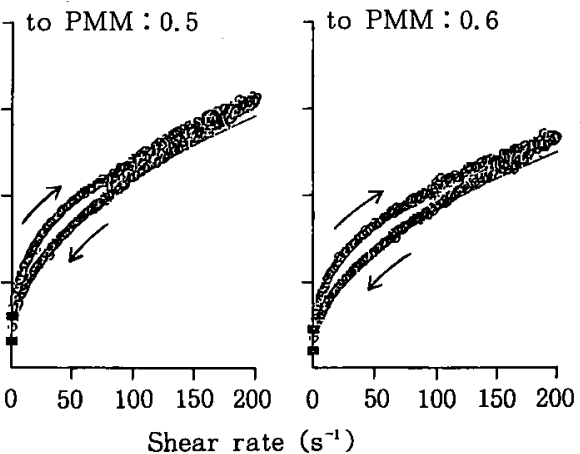

Fig. 1 Effect of yolk content on continuous flow curve of new emulsified product

The arrows along the experimental points indicate the increase or the decrease of shear rate in a continuous experiment. 
content shown as its ratio to PMM. Since the structure was broken down by the shear rate applied during the upcurve, the yield stress of the downcurve was small in the product with any egg-yolk content. It is shown that in the product with a low egg-yolk content, the structure breakdown was significant during the measurement. As a result, the difference in the yield stress value was large between the upcurve and downcurve. The power law equation was fitted to the shear rate sweep curve in Fig. 1, and the parameters thus derived are shown in Fig. 2. The power law equation was written as :

$$
p=B \dot{e}^{n}+C
$$

where $p$ is shear stress $(\mathrm{Pa}), \dot{e}$ is shear rate $\left(\mathrm{s}^{-1}\right), B$ is consistency index $\left(\mathrm{Pa} \cdot \mathrm{s}^{n}\right), C$ is yield stress $(\mathrm{Pa})$ and $n$ is flow behavior index. When either the $B$ value or $n$ value becomes large in this equation, the shear stress, $p$, increases. The change in $B$ value for the eggyolk content was similar between the upcurve and downcurve. As the ratio of egg-yolk increased from 0.1 to 0.3 , the $B$ value became larger. As yolk-ratio increased from 0.3 to 0.6 , the $B$ value became smaller. The change in $\mathrm{n}$ value was similar between the upcurve and downcurve with increasing yolk-ratio from 0.3 to 0.6 where $n$ increased to some extent. When the yolk-ratio increased from 0.1 to 0.3 , the $n$ value decreased in the upcurve and increased in the downcurve. Therefore, with yolk-ratios of 0.1 and 0.2 , the shear stress was large in the upcurve depending on large $\mathrm{n}$ values and small in the downcurve depending on small $\mathrm{n}$ values. As a result, the structure breakdown was great with these yolk-ratios. Since both the $B$ and $n$ values were small in the downcurve with these yolk-ratios, the shear stress was smaller when compared with other yolk-ratios. The product with a yolk-ratio of 0.2 showed two values for $B, C$ and $\mathrm{n}$ because it was in the transition state from a shear-unstable emulsion to a shear-stable one.

The yield stress obtained from compressive measurements of the flow property is shown in Fig. 3 in order to visualize the relationship of applied force $(\mathrm{N})$ and yolk-ratio as a three-
Emulsifier : Egg-yolk
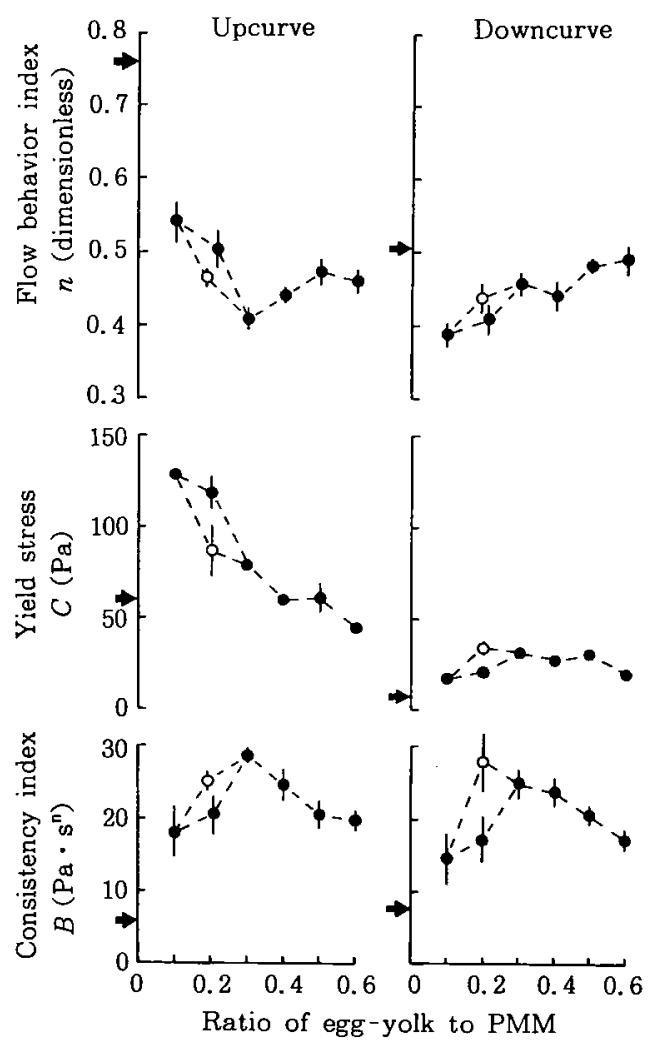

Fig. 2 Effect of yolk content on rheological parameters obtained from continuous flow curve

Arrows on the ordinate indicate the parameter values for French type commercial mayonnaise.

The solid and open circles at yolk ratio of 0.2 correspond to the samples which showed large and small areas of the hysteresis loop at yolk ratio of 0.2 in Fig 1, respectively.

Symbols with vertical bars indicate means $\pm \mathrm{SD} \quad(\mathrm{n}=8)$, and the symbols without vertical bar indicate that the sizes of standard deviation bar $(n=8)$ are smaller than the symbol.

dimensional surface plot. The yield stresses detected with different applied forces were in general agreement. The yield stress decreased with the increase of yolk-ratio, and this relation for the compressive measurement of flow 
property had the same tendency as in the upcurve for the rotational measurement of flow property. The absolute values of yield stress were almost the same in both measurements.

The hysteresis loop area surrounded by the
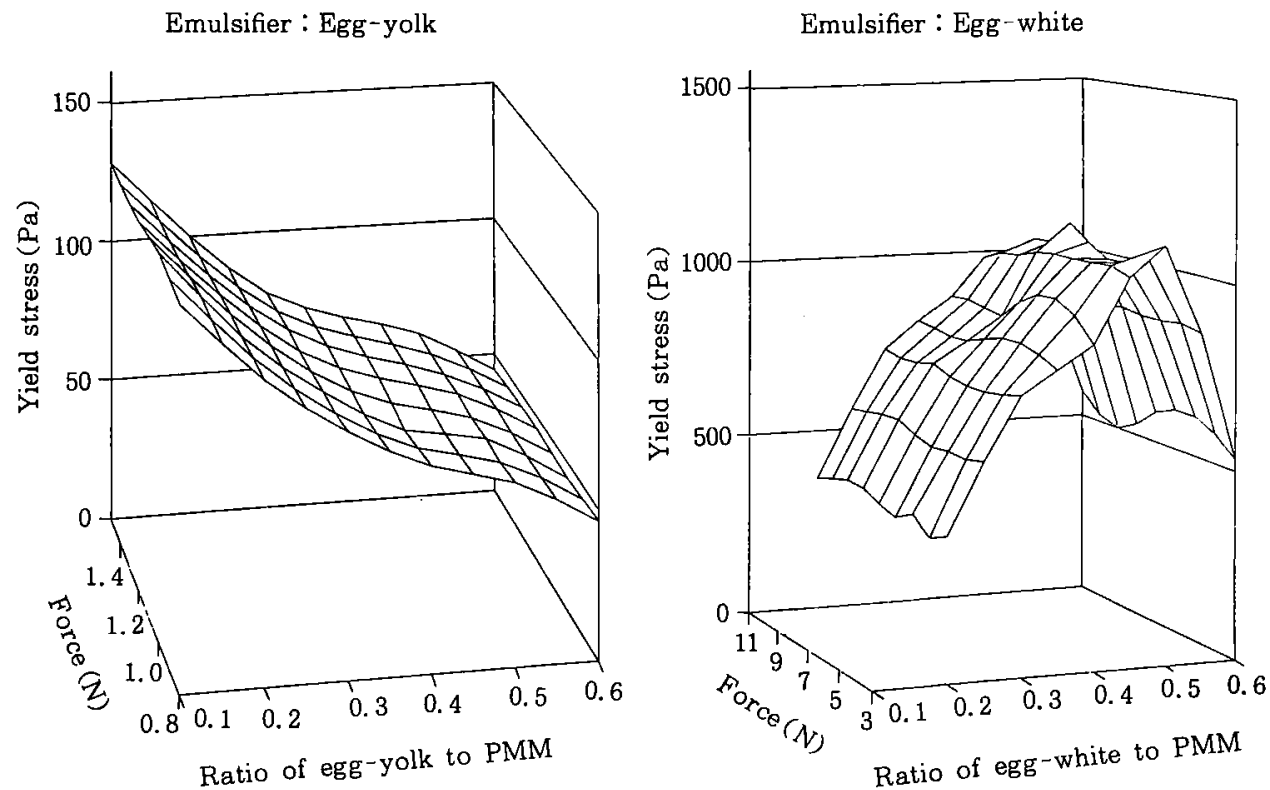

Fig. 3 Effect of yolk or white content on three-dimensional surface plots for yield stress obtained by compressive measurement
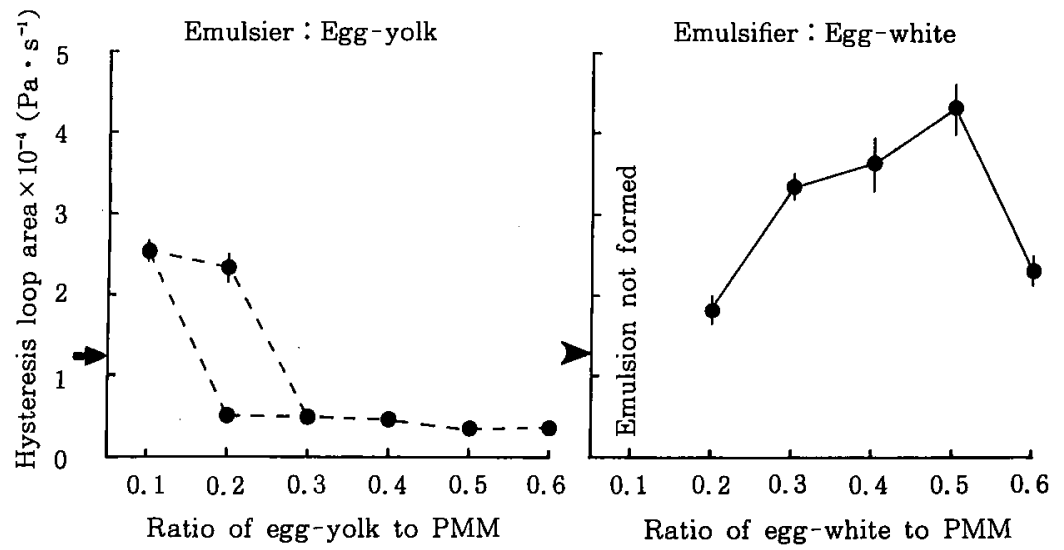

Fig. 4 Effect of yolk or white content on hysteresis loop area surrounded by upcurve and downcurve of rotational measurement

Arrows on the ordinates indicate area value for French type (left) and American type (right) commercial mayonnaise.

Symbols with vertical bars indicate means $\pm S D(n=8)$, and the symbols without vertical bar indicate that the sizes of standard deviation bar $(n=8)$ are smaller than the symbol. 
upcureve and downcurve is shown with respect to yolk-ratio in Fig. 4. This area increases when the structure breakdown is remarkable during shear application. The area was large for a yolk-ratio of 0.1 while it was small for a yolk-ratio between 0.3 and 0.6 . Since the large and small values were obtained for the area with a yolk-ratio of 0.2 , the product with this yolk-ratio was in the transition state from a shear-unstable emulsion to a shear-stable one. For the yolk-ratio between 0.3 and 0.6 , the structure change induced by increasing shear rate was mostly recovered by the decreasing shear rate. In all cases for a yolk-ratio of 0.1 and several cases for a ratio of 0.2 , the structure change was not significantly recovered.

The storage modulus, $G^{\prime}$, and loss modulus, $G$ ", obtained by vibrational measurement of the flow property are shown in Fig. 5 . The former modulus was derived from the elasticity response and the latter from the viscosity response. Both $G^{\prime}$ and $G$ " decreased with the increase of yolk-ratio. This tendency coincided with that observed in the upcurve's yield stress of the rotational measurement of flow property and also in the yield stress of compressive measurement of flow property. The $G$ " value was larger than the $G^{\prime}$ value for the product with any yolk-ratio. With these $G^{\prime}$ and $G$ " values, our emulsified products had a sticky consistency but could flow with the application of force.

Consistency of emulsified product with various amounts of egg-white

The response to the rotational measurement of flow property is shown in Fig. 6 where the effect of egg-white content on the shear rate sweep curve is displayed. Since the power law equation could not be fitted to the behavior of the emulsified product in the increasing shear rate phase, the stress data first acquired into the computer was regarded as the yield stress, which was the maximum stress. The emulsion was not formed with a white-ratio of 0.1 and the yield stress increased with the increase in white-ratio from 0.2 to 0.4 , as shown in Fig. 7. The settled large values of yield stress

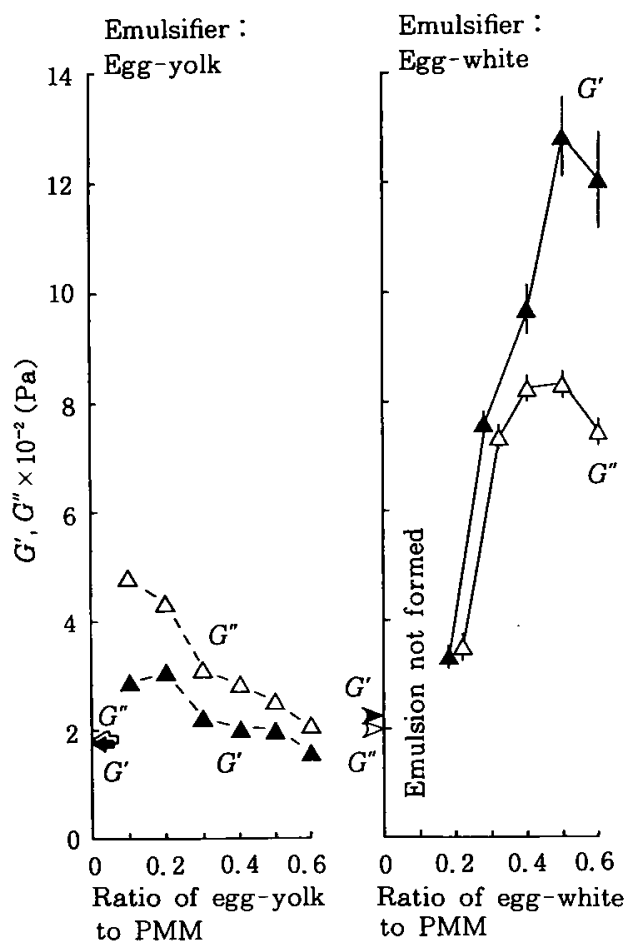

Fig. 5 Effect of yolk or white content on storage and loss moduli of new emulsified product

Arrows on the ordinates indicate modulus values for French type (left) and American type (right) commercial mayonnaise.

Symbols with vertical bars indicate means $\pm S D(n=8)$, and the symbols without vertical bar indicate that the sizes of standard deviation bar $(n=8)$ are smaller than the symbol.

were detected for white-ratios from 0.4 to 0.6 .

The hysteresis loop area shown in Fig. 4 increased with the increase in white-ratio from 0.2 to 0.5 but decreased with a ratio of 0.6 .

The yield stress obtained from compressive measurement of the flow property increased with the increase in white-ratio from 0.2 to 0.5 and decreased with the ratio of 0.6 , as shown in Fig. 3. This tendency coincided with that observed in the hysteresis loop area of rotational measurement of the flow property. For the white-ratios of 0.2 to 0.5 , the yield stress 


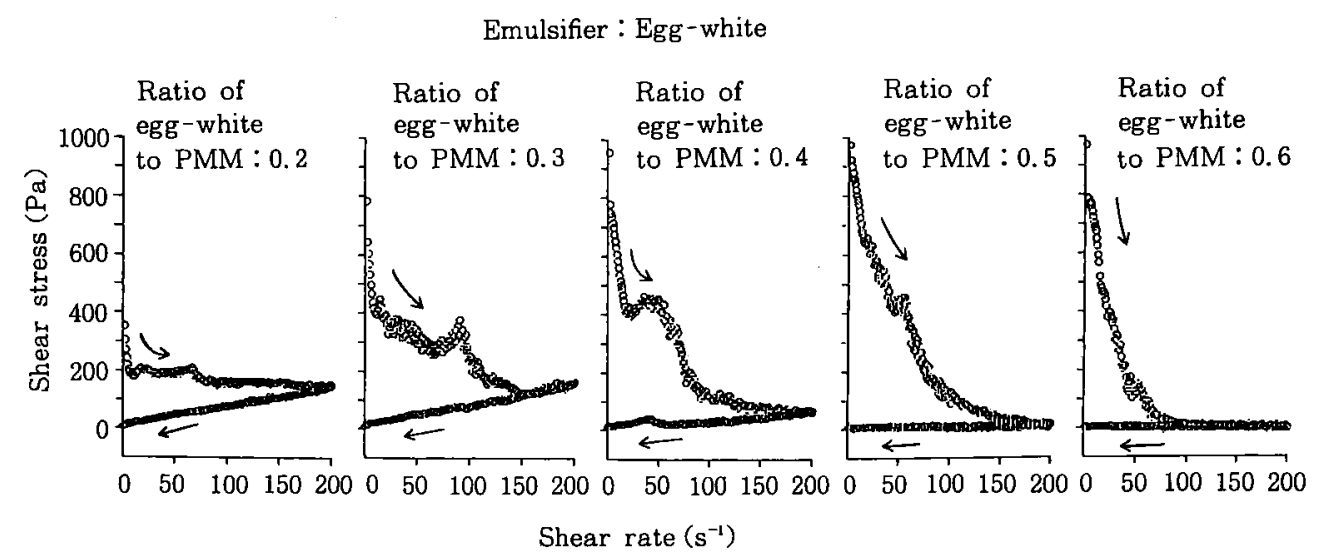

Fig. 6 Effect of white content on continuous flow curve of new emulsified product The arrows along the experimental points indicate the increase or the decrease of shear rate in a continuous experiment.

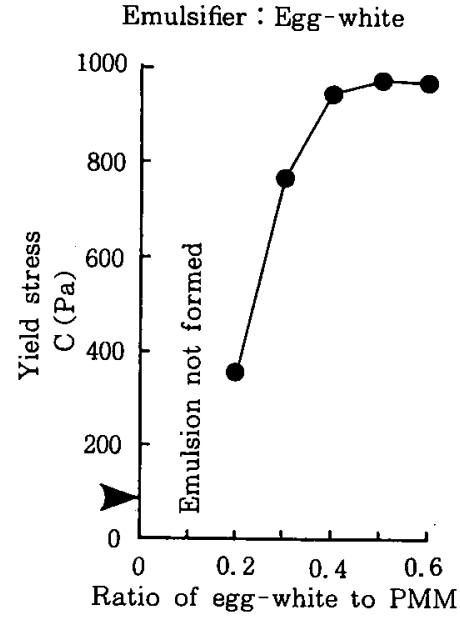

Fig. 7 Effect of white content on yield stress obtained from continuous flow curve

An arrow on the ordinate indicates the yield stress value for American type commercial mayonnaise.

All the symbols without vertical bar indicate that the sizes of standard deviation bar $(\mathrm{n}=8)$ are smaller than the symbol.

values obtained from the compressive measurement of the flow property were almost the same as those obtained from the upcurve of the rotational measurement of the flow property.
However, for the ratio of 0.6 , the former yield stress value was one-half of the latter. The structure breakdown was greater during compressive measurement of the yield stress than during rotational measurement.

Both the storage modulus, $G^{\prime}$, and loss modulus, $G$ ", increased with the increase in white-ratio from 0.2 to 0.5 but decreased for the ratio of 0.6 (Fig. 5). For the ratios of 0.2 and 0.3 , the $G^{\prime}$ value was almost equal to the $G$ " value while for the ratios of 0.4 or more, the former value was larger than the latter. When the $G^{\prime}$ value was almost the same as the $G$ " value, the emulsified product was considerably sticky and could barely flow with the application of force. However, when the $G^{\prime}$ value became larger than the $G^{\prime \prime}$, the product was brittle and difficult to flow even with the application of force. The $G^{\prime}$ and $G$ " values of the white-added product were much larger than those of the yolk-added product. This result agreed with the tendencies obtained from the rotational and compressive measurements of yield stress. The differences in the $G^{\prime}$ and $G^{\prime \prime}$ values between the yolk-added product and the white-added product were somewhat smaller than the difference in the yield stress value between these products. This is due to the following reason. The extent of structure breakdown was very small in the vibrational $G$ ' and $G$ " measurement while the two types of 
yield stress measurements were done with the forced structure breakdown.

The previously mentioned results are summarized as follows. The yolk-added product flowed much easier than the white-added product. When the white ratio was 0.6 , the product no longer flowed and was brittle. Accordingly, as the yolk ratio increased, the product became softer and showed smaller values for yield stress, $G^{\prime}$ and $G^{\prime \prime}$. The yolkadded product showed much smaller values in yield stress, $G$ ' and $G$ " than the white-added product.

\section{Discussion}

The egg-white is known to have a weaker emulsifying ability as compared with eggyolk ${ }^{5}$. It is considered that the large yield stress of the white-added emulsified product will relate to the yield stress of the emulsified product with whole egg. The $\mathrm{pH}$ significantly changed from $8.0-8.1$ for fresh egg-white to $5.3-5.4$ for white-added emulsified product as compared with the small change in $\mathrm{pH}$ from 6.0 for fresh egg-yolk to 5.1 for yolk-added emulsified product. The isoelectric $\mathrm{pH}$ of ovalbumin, the major protein in egg-white, is $4.5^{6)}$. The $\mathrm{pH}$ of white-added product was near this $\mathrm{pH}$ and the lack of repulsive forces led to the formation of a less expanded, less hydrated gel. Therefore, the white-added product showed a brittle response in our experiment.

For the product having white ratio of 0.6 , the compressive yield stress was one-half of the rotational one. During the measurement of the compressive yield stress, since the diameter of the parallel plates was smaller than the diameter of the sample, the diameter of sample subjected to the shearing forces was constant. With the applied constant force, the samples that exhibit a yield stress have both sheared and unsheared regions between the parallel plates ${ }^{4)}$. In our experiment, the initial sample height was $0.6 \mathrm{~cm}$ and the limiting height was usually between $0.1 \mathrm{~cm}$ and $0.2 \mathrm{~cm}$. At the instant of force application, the maximum shear rate of $0.83 \mathrm{~s}^{-1}$ was induced due to the moving speed of the bottom plate set at $5 \mathrm{~mm} / \mathrm{s}$. The shear rate gradually decreased and asymptotically approached zero. The rotational yield stress was obtained at the beginning of the shear application while the compressive one was obtained at the end. Since the emulsified product with a white-ratio of 0.6 was brittle, its structure was easily broken down by such a compressive low-shear application as was previously mentioned. Therefore, the compressive yield stress value was smaller than the rotational one due to a significant structure breakdown, even if normal stress was induced at the instant of rotational shear application. The brittle response of the product with a white-ratio of 0.6 was also understood from the fact that the hysteresis loop area was remarkably small and the structure was easily broken down by increasing shear rate.

The consistency index $B$ is regarded as the apparent viscosity at the shear rate of $1 \mathrm{~s}^{-1}$ because shear stress, $p$, becomes the sum of the consistency index, $B$, and yield stress, $C$, independently of the $\mathrm{n}$ value with a shear rate of $1 \mathrm{~s}^{-1}$. The $B$ value of the yolk-added product was larger than that of commercial mayonnaise, and the value was a maximum with medium amount of yolk (yolk ratio= $0.3)$. These results mean that the interaction between PMM and yolk is related to the increase in the $B$ value.

When the diameter distribution of oil droplets is monodisperse, the flow behavior index, $n$, is close to one. When the distribution is extremely polydisperse, the $n$ value becomes considerably smaller than one and approaches zero. Since the commercial mayonnaise showed a homogeneous distribution of oil droplets, the $n$ value was large (0.77). Our own yolk-added product developed heterogeneous complicated structure with both PMM and oil, and as a result, the $n$ value was small $(0.41-0.54)$.

The extent of the hysteresis loop area is of ten related to the extent of thixotropic response, and the small value of the flow behavior index, $n$, of ten corresponds to the large area of the hysteresis loop. In this 
relation, the structure breakdown is still reversible (i.e., recoverable). However, in our present experiment, the structure breakdown was irreversible when the yolk ratio was 0.1 and 0.2 . This irreversible shear breakdown was induced in the emulsion structure formed mainly by the aid of PMM. In this emulsion, the flow behavior index, $n$, was large as was the hysteresis loop area. Three-dimensional shear-unstable emulsion structure with a large $n$ value was formed but it was easily broken down by the shear application. When the yolk ratio was 0.3 or more, the structure breakdown became reversible. This emulsion structure was formed with the aid of both egg yolk and PMM. As the yolk ratio increased from 0.3 to 0.6 , the flow behavior index, $n$, slightly increased and the hysteresis loop area slightly decreased. This result was the usual thixotropic response. In the white-added emulsified product, the flow behavior index could not be related to the hysteresis loop area because the flow behavior index was a negative value due to the extremely shear-unstable emulsion structure.

It is reliable that in the yolk-added emulsified product, the PMM played the emulsion-stabilizing and thickening roles, but for the sake of discussion of the emulsion structure, the total amount of constituents except PMM was assumed to be $100 \%$ where the corresponding constituents were yolk, soybean oil and vinegar. The ratio of yolk to total amount of constituents except PMM ranged from 7.5 to $32.6 \%$ while the corresponding ratio of soybean oil ranged from 82.1 to $59.8 \%$. The average yolk content of a French type commercial mayonnaise is about $8 \%{ }^{577}$. All yolk-added products used in this experiment contained enough amount of yolk as the emulsifying agent. The oil content of commercial mayonnaise is about $75 \%$ and its emulsion structure is in the closest packing state ${ }^{5 / 7)}$. The drastic change in shear rate sweep measurement was observed between our products with a yolk ratio of 0.2 and 0.3 . The ratio of soybean oil was 76.4 and $71.4 \%$ in these products, respectively. The remarkable struc- ture change in the product was induced by the shear application when the ratio of soybean oil was over $71.4 \%$. The ratio of soybean oil over $71.4 \%$ is near the oil content for a closest packing. Since the oil content is comparatively low in the products with a yolk ratio of 0.3 0.6 , the interaction between oil droplets was small. When the oil content was over $71.4 \%$ and approached the closest packing, the coalescence of oil droplets was induced by the shear application and the emulsion structure was easily broken down. In the products with a yolk ratio of 0.1 and 0.2 , the amount of yolk was small and consequently the ratio of yolk to oil was also small. Therefore, the emulsifying layer around an oil droplet was thin and the oil droplets tended to coalesce without shear. If shear was applied, the emulsion was easily broken down due to the further coalescence. From the microscopic observations (Fig. 8), it was found that the size of an oil droplet increased (mostly $2.2 \mu \mathrm{m}$ for a yolk ratio of $0.6,3.0 \mu \mathrm{m}$ for a ratio of $0.5,3.3 \mu \mathrm{m}$ for a ratio of $0.4,4.2 \mu \mathrm{m}$ for a ratio of $0.3,7.5$ $\mu \mathrm{m}$ for a ratio of 0.2 , and $13.3 \mu \mathrm{m}$ for a ratio of 0.1 ) and the number decreased with lower yolk ratio. This finding supports the previously mentioned discussion.

The stimulus associated with the oral evaluation of viscosity is the shear stress developed in the mouth at an approximately constant shear rate of $50 \mathrm{~s}^{-18)}$. In commercial mayonnaise, the power law equation could be fitted to the shear rate sweep data up to $50 \mathrm{~s}^{-1}$. When the shear rate was larger than $50 \mathrm{~s}^{-1}$, the structure was broken down and the fitted power law curve deviated from the experimental points (Fig. 9). In our product with a yolk ratio of $0.3-0.6$, the power law equation could be fit to the sweep data with increasing shear rate up to $200 \mathrm{~s}^{-1}$ and the sweep data of decreasing shear rate existed near the data of the increasing one. This means that the structure breakdown only slightly occurred in our yolk-added products. Since our yolk-added product had such a shear-stable smooth texture, it was superior to commercial mayonnaise as an emulsion-type food. 


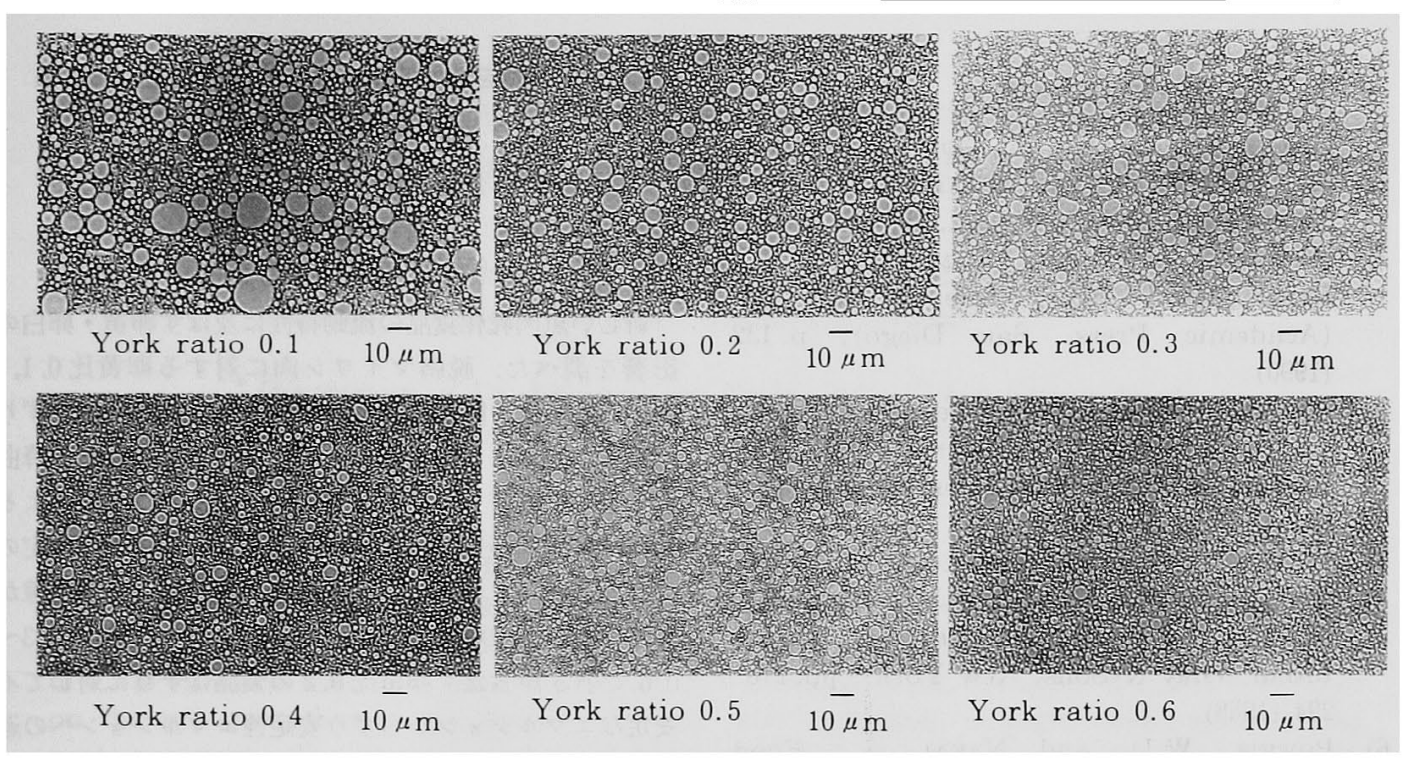

Fig. 8 Micrographs of new emulsified product

The bar indicates $10 \mu \mathrm{m}$.

The constituent ratio of the product was as follows.

PMM : egg-yolk : soybean oil : vinegar $=1: 0.1-0.6: 1.1: 0.14$

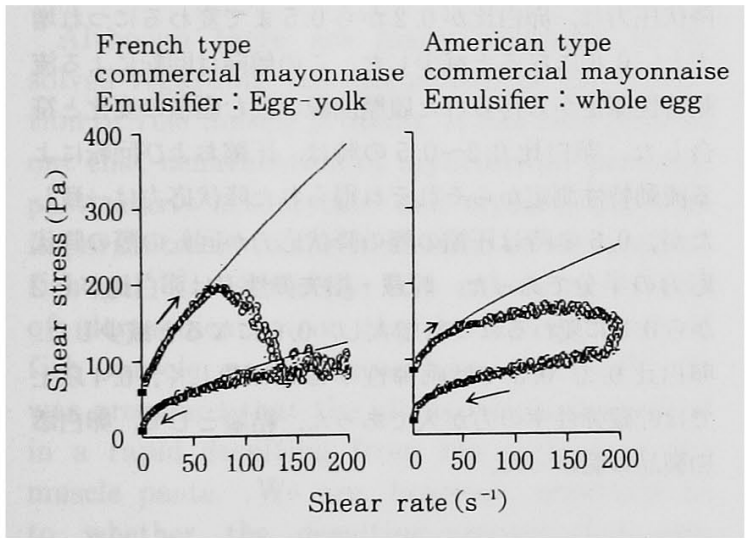

Fig. 9 Continuous flow curves of commercial mayonnaise

The arrows along the experimental points indicate the increase or the decrease of shear rate in a continuous experiment.

For the emulsified product such as mayonnaise and dressing, an appropriate fluidity and shear-stability are required. The yolk-added product showed much smaller values in yield stress, $G^{\prime}$ and $G^{\prime \prime}$ than the white-added product. The hysteresis loop area for the rota- tional measurement of the flow property was much smaller in the yolk-added product than in the white-added product. In the sensory evaluation, the yolk-added product exhibited a smooth palatability while the white-added product exhibited a brittle one. Therefore, since the yolk-added product showed the appropriate fluidity and shear-stability, it was superior in flow response to the white-added product.

A fishy odor was not detected in the yolkadded product but it was detected in the white-added product. In the sensory evaluation, our yolk-added product had a milder and less sour taste when compared with commercial mayonnaise. Our yolk-added product showed a larger $B$ value than commercial mayonnaise. In the sensory evaluation, our yolk-added product had a thicker and more relishable consistency than commercial mayonnaise. Therefore, it is concluded from the odor, taste and consistency evaluations that our product is promising as a dressing-type food. 


\section{References}

1) Nakayama, T., Oka, T., OoI, A., Nonaka, M., Hirata, F. and Saekr, H.: Nippon Shokuhin Kogyo Gakkaishi, 39, 451 (1992).

2) Penfield, M.P. and CAmpbell, A.M. : Experimental Food Science, 3rd ed. (Academic Press, San Diego), p. 132 (1990).

3) Sherman, P. : Sensory Properties of Foods, ed. by Birch, G.G., Brennan, J.G. and Parker, K.J. (Applied Science Publishers, London), p. 303 (1977).

4) Covey, G.H. and Stanmore, B.R.: $J$. Non-Newtonian Fluid Mech., 8, 249 (1981).

5) Lowe, B. : Experimental Cookery, 4th ed. (John Wiley \& Sons, New York), pp. 278294 (1958).

6) Powrie, W.D. and NakaI, S.: Food Chemistry, 2nd ed., ed. by Fennema, O.R. (Marcel Dekker, New York), p. 835 (1985).

7) Romanoff, A.L. and Romanoff, A.J. : The Avian Egg, lst ed. (John Wiley \& Sons, New York), pp. 776-778 (1949).

8) Shama, F. and Sherman, P.: J. Texture Studies, 4, 111 (1973).

(Received Jun 2. 1992)

\section{ずり安定性を有する魚肉乳化食品の製造における 卵黄と卵白の効果 \\ 中山照雄 ${ }^{*}$ 户崎由美子* ・若林敦子 ${ }^{*} \cdot$ 大井淳史 ${ }^{*}$ \\ *三重大学生物資源学部

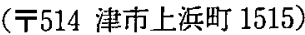

新しい魚肉乳化食品の流動特性に及ぼす卵黄・卵白の 影響を調べた，脱脂マイワシ肉に対する卵黄比 0.1 , 0.2 の製品は，回転による流動特性測定において，ずり 応力す外力による降伏応力すずり速度上昇曲線と下降曲 線で著しく異なり，構造破壊が大きかった，圧縮による 流動特性測定から得られた降伏応力は回転による測定の あのとほぼ等しかった．ずり速度上昇曲線と下降曲線が 描く履歷曲線の囲む面積は卵黄比 0.1 で大きく，0.3 0.6 で小さかった．卵黄比 0.2 の製品はずりに対して不 安定なエマルションからずり安定性エマルションへの過 渡状態にあった，卵黄比の增加上とあに眝蔵・損失弾性 率は減少し，いずれの卵黄比であ損失弾性率の方が大き かった，結諭として，卵黄比 0.3 以上ではずり安定性エ マルションが調製できた

卵白添加製品の圧縮による流動特性測定から得られた 降伏圧力は, 卵白比が 0.2 から 0.5 まで変わるにつれ增 大し，0.6になると隇少した。この傾向は回転による流 動特性測定加ら得られた履歴曲線の囲む面積の変化之符 合した，卵白比 0.2 0.5の時は，圧縮および回転によ る流動特性測定からそれぞれ得られた降伏応力は一致し たが， 0.6 の時は圧縮の際の降伏応力が回転の際の降伏 応力の半分であった。眝蔵・損失弹性率は卵白比が 0.2 から0.5に変わるにつれ増大し，0.6になると減少した。 卵白比 $0.2 ， 0.3$ では両弾性率はほぼ等しく, 0.4 以上 では眝蔵弾性率の方が大であった，結論として，卵白添 加製品は脆かった。 